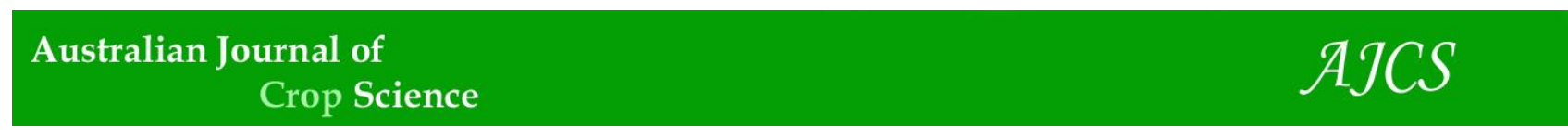

AJCS 10(3):393-401 (2016)

ISSN:1835-2707

DOI: $10.21475 /$ ajcs.2016.10.03.p7236

\title{
Applying wood ash and soil moisture on gladiolus (Gladiolus grandiflorus) cultivation
}

\author{
Marcel Thomas Job Pereira, Tonny José Araújo da Silva, Edna Maria Bonfim-Silva*, Renata Bachin \\ Mazzini-Guedes
}

Institute of Agricultural Sciences and Technology, Federal University of Mato Grosso, Department of
Agricultural and Environmental Engineering, Rondonopolis, Mato Grosso, Brazil

*Corresponding author: embonfim@hotmail.com

\begin{abstract}
The management of fertilization using burnt residue from plant material associated with the management of irrigation, has demonstrated the possibility of a sustainable strategy to increase production of ornamental plants cultivated in greenhouses. The objective of this study was to evaluate the development of gladiolus plants cultivated in the Cerrado Rhodic Hapludox and subjected to doses of wood ash and volumetric soil moistures. The experiment was conducted under controlled conditions, from April to June 2014. The experimental design was arranged in randomized blocks, in a $5 \times 5$ factorial scheme, totaling 25 treatments, with four replications. Treatments were composed of five doses of wood ash $\left(0,8,16,24\right.$, and $\left.32 \mathrm{~g} \mathrm{dm}^{-3}\right)$, and five volumetric soil moistures $(7,14,21,28$, and 35\%). Evaluated variables were: $\mathrm{pH}$ and soil water retention capacity; length of flower spikes and flower stems; flower numbers; and days from plant emergence to flowering. Results were analyzed using the response surface methodology with SAS software. The best results for length of flower spikes and flower stems depend on the combination of appropriate doses of wood ash and soil moisture levels. Number of flowers and days from plant emergence to flowering was separately influenced by either doses of wood ash or soil moisture, which ranged from 8 to $12 \mathrm{~g} \mathrm{dm}^{-3}$ wood ash, and 33 to $35 \%$ soil moisture. The ash may be used as both soil corrective and fertilizer for greenhouse gladiolus production, besides improving soil water retention capacity. The ideal volumetric soil moisture for flower production is $33 \%$.
\end{abstract}

Keywords: Gladiolus grandiflorus; Andrews; irrigation management; ornamental plant; solid residue in agriculture.

Abbreviations: pH_hydrogen potential; P_phosphorus; Ca_calcium; Mg_magnesium; H_hydrogen; Al_aluminum; SB_sum of the bases; CEC_cation exchange capacity; V_base saturation; OM_organic matter; Al sat_aluminum saturation; NV_neutralizing value; N_nitrogen; Zn_zinc; Cu_copper; B_boron; S_sulfur; Si_silicon; Fe_iron KPa_kilopascals; ATP_adenosine triphosphate; SAS_statistical analysis system; RSREG_regression procedures; GLM_command general linear model procedure.

\section{Introduction}

The production sector for flowers and ornamental plants in Brazil has consistently been consolidating more significant positions in agribusiness, standing out as an economically growing activity, which, in addition to adding high potential for future expansion (Junqueira et al., 2014) also represents the main activities that generate occupation, employment and income for large and small producers throughout the country. In Brazil, the gladiolus (Gladiolus spp), also known as Palma-de-Santa-Rita, has economic importance both in producing flowers, such as for the production of corms. The nutritional requirements of this culture are variable due to the different varieties and growing conditions such as soil moisture. Water stress, especially in large variations of soil moisture, reflect a precarious and uneven development of the final product. For the gladiolus, the deficiency in water supply affects the vegetative growth and flowering, forming clumps with reduced length (Carvalho et al., 2001). The gladiolus plants thrive in warm weather conditions, good availability of water throughout the cycle, soil with good drainage, fertile and rich in organic matter, and soil $\mathrm{pH}$ in the range of 5.5 to 6.5 (Lu et al., 1996; Al-Humaid, 2004. For insertion of Cerrado soils in the production process which are characterized by low soil fertility, high acidity and low levels of nutrients such as calcium, magnesium, potassium and phosphorus (Bastos and Ferreira, 2010), the use of corrective agricultural and mineral fertilizers are needed. However, the high cost of fertilizers and a generated demand for inclusion of low-cost alternative materials in the production system, among which stand out vegetable ash and solid waste produced on a large scale in the central west of Brazil. Igbokwe et al. (1981) speculated that the use of ash in agriculture is ecologically viable and economically interesting because once incorporated in the soil, it improves moisture retention capacity, partially corrects acidity, and provides improvement in crop growth (Nkana et al., 1998a; Mozaffari et al., 2002; Lobermann-Eichler et al., 2008). Vegetable ash has a high content of oxides, hydroxides, calcium and magnesium carbonates (Haraldsen, et al. 2011), thus improving soil fertility, which involves reduction of $\mathrm{H}^{+}$ Al content, pH increase in soil (Osaki and Darolt, 1991; Maeda et al., 2008; Ferreira et al., 2012), and introduces in the soil significant amounts of basic cations, such as potassium (Nordstrom et al., 2012). Ojeniyi et al. (2001) found that the yield of vegetable and crop nutrient content have been improved with the use of vegetable ash in the southeast of Nigeria. Likewise, Adetunji (1997) and Odedina et al. (2003) reported reduced and greater availability of cations in soils with vegetable ash acidity. 
Omoti et al. (1991) and Ndubuisi and Deborah (2010) observed improvement in soil properties $(\mathrm{pH}, \mathrm{Ca}, \mathrm{Mg})$ which, in turn, increased the grain yield of maize. Ferreira et al. (2012) and Mittra et al. (2005) observed the positive effects of vegetable ash in Cerrado soils. The results showed a significant improvement in some physical properties (bulk density) and chemicals ( $\mathrm{pH}$, potassium, and magnesium). Thus, the use of vegetable ash in agricultural cultivations is presented as a form of restoration of nutrients removed by the crops, improving productivity and minimizing polluting effects, given the high quantity of ash produced in the region. Inside the study area, Mato Grosso in west central Brazil, the information regarding the fertilizer recommendation with vegetable ash and water from gladiolus conditions are scarce. Given the above, the objective was to evaluate the effect of doses of plant ash and soil moisture in the development and production of gladiolus White Friendship in Oxisol of the Cerrado, in order to make recommendations on the appropriate levels for the production of gladiolus in greenhouses.

\section{Results and Discussion}

\section{Soil water retention capacity}

The soil water retention capacity significantly increased with addition of wood ash and was adjusted to the linear regression model. Soil with no wood ash presented water retention of $30.58 \%$, while the greatest dose of wood ash (32 $\mathrm{g} \mathrm{dm}^{-3}$ ) promoted $33.16 \%$ water retention capacity (Fig. 1). Soil water retention is a specific characteristic of each type of soil as a result of either natural or anthropic modifications in the organic matter content, structure (Reichardt, 1988), clay fraction content and mineralogy (Ferreira et al., 1999), and soil density (Beutler et al., 2002), among others. According to Bellote et al. (1998), application of doses of wood ash increased the organic matter in the soil and, thus, its water retention capacity. In this condition, field capacity $(0.30 \mathrm{~atm})$ and the wood ash enhanced the ability of soil to retain 12 $14 \%$ water, compared to the control in all treatments. These same authors have shown that doses of $50 \mathrm{t} \mathrm{ha}^{-1}$ improved water retention in the soil. Therefore, the gain of organic matter from application of wood ash may be responsible for the increase in capacity of soil water retention found in this study. Such results corroborate those reported by Kiehl (1979), who verified a positive correlation between the soil organic matter content and its water retention capacity. Organic matter is a source of nutrients as it increases water retention capacity, improves soil structure, porosity, decreases the bulk density, consistency, color, and so on (Lopes, 1989; Conceicão et al., 2005). Thus, the increase in water retention capacity of the soil promotes root development, particularly in regions with risks of periods of drought; better stability of the aggregates and reduce the flow of surface water, reducing the risks of erosion (Conceicão et al., 2005). As wood ash raises the retention capacity of soil water, it may be used in agriculture with the aim to maximize storage of soil water during periods of greater rainfall, and to make it available during times of water deficit. The increase in soil water retention capacity optimizes water use, reducing irrigation water consumption, and contributing towards a decrease in nutrients leaching through the soil profile under field conditions.

\section{Soil pH after incubation with wood ash}

Soil $\mathrm{pH}$ was linearly influenced by addition of wood ash in the soil at 30 days of incubation (before corm planting) and, also at 150 days (at corm harvest). There was an increment in $\mathrm{pH}$ values of 44.50 and $18.28 \%$ at 30 and 150 days, respectively, when the greatest wood ash dose treatment (32 $\mathrm{g} \mathrm{dm}^{-3}$ ) was compared with the control (no wood ash addition) (Fig. 2). The $\mathrm{pH}$ values have a linear relationship with the doses of ash studied, indicating that $\mathrm{pH}$ increases proportional to the quantity of ash added. The $\mathrm{pH}$ increases can be attributed mainly to the release of potassium carbonate by reaction of ash in the soil. Potassium carbonate is more than half of the soluble part of the ash (Rigau, 1960). This indicates that increasing amounts of applied ash remained, probably reacting with the soil. Such $\mathrm{pH}$ increase response, around 3.50 and $1.02 \mathrm{pH}$ units verified at 30 and 150 days, respectively, occurred due to the chemical composition of the wood ash used in this study; it presented substantial amounts of calcium, magnesium, potassium, and phosphorus (Table 2 ), confirming results described by Moro and Gonçalves (1995). These results corroborate Demeyer et al. (2001) confirming that the increase of the soil $\mathrm{pH}$ and decrease of exchangeable $\mathrm{Al}$ content of acidic soils' high alkalinity of the ash and raising the $\mathrm{pH}$ of the soil solution was partly due to the reaction between $\mathrm{SO}_{4}$ ash and $\mathrm{OH}^{-}$ions in the soil (Nkana et al., 1998b). Park et al. (2005) developed research with applications of wood ash for three years, at rates of 0,10 , and $20 \mathrm{t} \mathrm{ha}^{-1}$ in willow (Salix purpurea), and found increased soil $\mathrm{pH}$ in the $0-10 \mathrm{~cm}, 6.1$ the dose control to 6.9 , and 7.1 at doses of 10 and $20 \mathrm{t} \mathrm{ha}^{-1}$, respectively. Application of ash also increased extractable phosphorus content and levels of potassium, calcium, and magnesium in the soil. Also, the plant stems presented greater length compared to the control. Silva et al. (2013), when working with wood ash as a corrective of humic inceptisol acidity and fertility, obtained a less expressive response on $\mathrm{pH}$ unit raise in comparison with the results found in this study. This may have happened due to either the high humic inceptisol buffering acidity or different characteristics of the residues used in both studies. Those authors used wood ash of $7 \%$ neutralizing value while the wood ash in this study presented $25 \%$ (Table 2).

Silva (2008), when studying effects of forest biomass ash on attributes of acidic soils, observed that soil $\mathrm{pH}$ (inceptisol and oxisol) was not significantly changed with application of increasing ash doses, contradicting the results of this and other studies (Darolt et al., 1993; Guerrini et al., 1994; Khanna et al., 1994; Prado et al., 2002). At 150 days, at the end of the experimental period, we observed the same soil $\mathrm{pH}$ linear response with addition of wood ash; however, $\mathrm{pH}$ values were lower than those verified at the beginning, possibly due to soil-plant interaction, which ion exchange among gladiolus plants and soil promoted its acidification. This occurs when plants absorb more cations than anions, promoting $\mathrm{H}^{+}$excretion by the roots and reducing the medium $\mathrm{pH}$ (Malavolta, 1976).

\section{Length of flower spikes and stems}

There was a significant interaction among doses of wood ash and soil moistures for length of flower spikes and of flower stems at harvest, which results were adjusted in the response surface study to the regression polynomial model (Figs. 3 and 4). From the response surface study for length of flower spikes, we observed that a dose of wood ash of $12.95 \mathrm{~g} \mathrm{dm}^{-3}$, associated with $34.26 \%$ volumetric soil moisture, promoted the greatest length (Fig. 3). However, for flower stem, maximum length was obtained by $19.35 \mathrm{~g} \mathrm{dm}^{-3}$ wood ash combined with $31.30 \%$ volumetric soil moisture (Fig. 4). Length of flower spike is an important variable to evaluate plant potential for flower production, as the greater its length, 
Table 1. Chemical and particle size analysis of a Rhodic Hapludox sample collected from 0.00-0.20 m depth.

\begin{tabular}{|c|c|c|c|c|c|c|c|c|c|c|c|c|c|c|c|}
\hline $\mathrm{pH}$ & $\mathrm{P}$ & $\mathrm{K}$ & $\mathrm{Ca}$ & $\mathrm{Mg}$ & $\mathrm{H}$ & $\mathrm{Al}$ & SB & CEC & $\mathrm{V}$ & O.M. & $\mathrm{H}$ & $\mathrm{Al}$ sat & Sand & Silt & Clay \\
\hline $\mathrm{CaCl}_{2}$ & \multicolumn{2}{|c|}{$\mathrm{mg} \mathrm{dm}^{-3}$} & \multicolumn{6}{|c|}{.. $\mathrm{Cmol}_{\mathrm{c}} \mathrm{dm}^{-3}}$. & $\%$ & $\mathrm{~g} \mathrm{dm}^{-3}$ & \multicolumn{2}{|c|}{$\ldots . . \% \ldots$} & & $\mathrm{gg}^{-1}$ & \\
\hline 4.2 & 1.1 & 29 & 0.6 & 0.3 & 5.7 & 0.5 & 0.6 & 7.3 & 13 & 28.7 & 79 & 35 & 549 & 84 & 367 \\
\hline
\end{tabular}

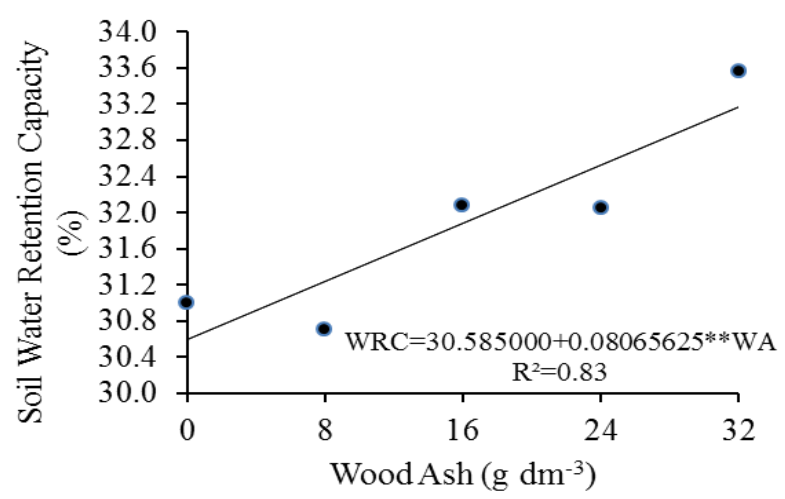

Fig 1. Soil water retention capacity (WRC), according to wood ash (WA) doses, in Rhodic Hapludox.

Table 2. Wood ash chemical analysis as a fertilizer.

\begin{tabular}{|c|c|c|c|c|c|c|c|c|c|c|c|c|c|}
\hline $\begin{array}{l}\mathrm{pH} \\
\left(\mathrm{H}_{2} \mathrm{O}\right)\end{array}$ & $\mathrm{NV}^{\mathrm{a}}$ & $\mathrm{N}$ & $\begin{array}{l}\text { Total } \\
\mathrm{P}_{2} \mathrm{O}_{5}\end{array}$ & $\mathrm{~K}_{2} \mathrm{O}$ & $\mathrm{Zn}$ & $\mathrm{Cu}$ & $\mathrm{Mn}$ & B & $\mathrm{Ca}$ & $\mathrm{Mg}$ & $S$ & $\mathrm{Si}$ & $\mathrm{Fe}$ \\
\hline 11.8 & 25 & 0.25 & 4.85 & $\begin{array}{c}\ldots \ldots \ldots . . \\
1.66\end{array}$ & 0.013 & $\begin{array}{l}\ldots \% \\
0\end{array}$ & .......... & 0.02 & 3.75 & 2.85 & 0.28 & 18.7 & 1.53 \\
\hline
\end{tabular}

${ }^{\mathrm{a}} \mathrm{NV}=$ Neutralizing Value

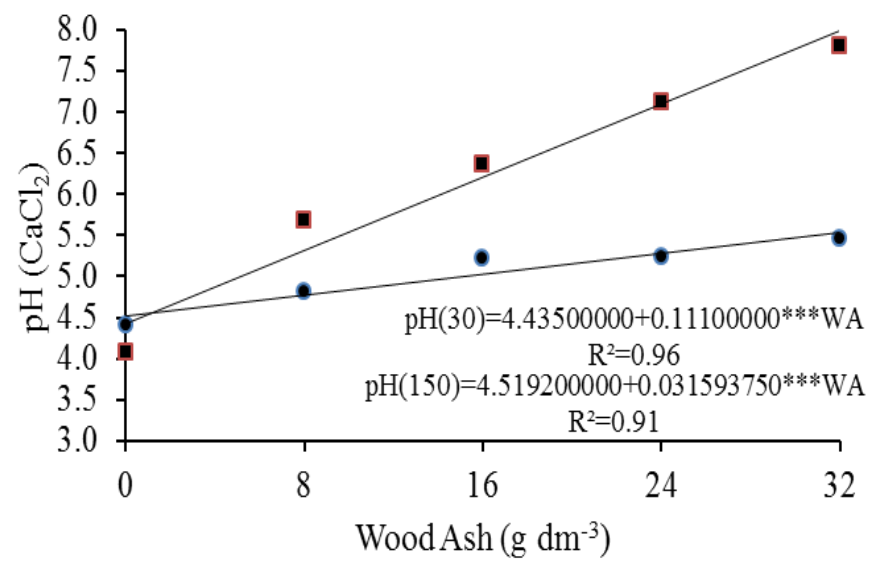

Fig 2. Soil $\mathrm{pH}$ at 30 days (pH30), before corm planting, and at 150 days ( $\mathrm{pH} 150$ ) at the end of the experimental period, according to wood ash (WA) doses, in Rhodic Hapludox. ***Significant at $0.1 \%$.

the greater the number of flower buds. The combination of wood ash dose of $12.95 \mathrm{~g} \mathrm{dm}^{-3}$, associated with $34.26 \%$ volumetric soil moisture promoted flower stems of $148 \mathrm{~cm}$ length, which would be classified, according to its length, as 'Extra' (Table 3), that is, the highest quality standard. According to Tombolato (2004), top dressing of nitrogen and potassium are important for longer flower stem production. Our results, however, show the primary importance on such variable of the potassium derived from wood ash, since the nitrogen fertilization was the same for all treatments. Regarding the reduction in length of flower stems according to lower soil moisture, Borges (2005) and Pereira et al. (2009) also observed that the water deficit promoted a decrease in gladiolus flower production as well as in flower stem quality for commercial purposes. According to Pereira et al. (2009) and Carvalho et al. (2001), it is possible to obtain longer flower stems when soil water pressure is kept close to field capacity during all gladiolus phenological stages, indicating that more frequent irrigations are most recommended. The use of weekly supplementary fertilization with $25 \mathrm{~g} \mathrm{~m}^{-2} \mathrm{KNO}_{3}$ two weeks before harvest of corms, anticipated harvest, and increased the percentage of flowering, length and diameter of the flower stem, and the number of flowers per culture floral spike (Karagüzel et al., 1999). Plants cultivated under $7 \%$ volumetric soil moisture did not produce flowers, remaining only in the vegetative stage, which indicates the susceptibility of gladiolus to water deficits. This may have occurred because both growth and flowering stages are sensitive to variations in soil moisture. Halevy (1962) found two susceptibility stages of gladiolus plants to water deficit: the first, during initial growth and, the second from the growth of the fourth leaf to flower stem 
Table 3. Chemical characterization of the soil after the application of wood ash treatments at 60 days of incubation.

\begin{tabular}{|c|c|c|c|c|c|c|c|c|c|c|}
\hline \multirow{2}{*}{$\begin{array}{l}\text { Treatment } \\
\text { Wood ash } \\
\left(\mathrm{g} \mathrm{dm}^{-3}\right)\end{array}$} & $\mathrm{pH}$ & $\mathrm{P}$ & $\mathrm{K}$ & $\mathrm{Ca}$ & $\mathrm{Mg}$ & $\mathrm{Al}$ & $\mathrm{H}$ & CTC & OM & $\mathrm{V}$ \\
\hline & $\mathrm{CaCl}_{2}$ & \multicolumn{3}{|c|}{$\ldots \mathrm{mg} \mathrm{dm}^{-3} \ldots$} & \multicolumn{4}{|c|}{..........cmolc $\mathrm{dm}^{-3} \ldots \ldots \ldots$} & $\mathrm{g} \mathrm{dm}^{-3}$ & $\%$ \\
\hline 0 & 4.08 & 3.4 & 34 & 0.5 & 0.2 & 0.7 & 4.8 & 6.2 & 24.1 & 12.6 \\
\hline 8 & 5.68 & 28.6 & 1090 & 1.5 & 2.5 & 0 & 3.5 & 10.3 & 39.9 & 66.5 \\
\hline 16 & 6.36 & 88.5 & 2690 & 2.0 & 4.1 & 0 & 2.3 & 15.4 & 47.1 & 84.9 \\
\hline 24 & 7.11 & 103.6 & 3240 & 2.2 & 4.5 & 0 & 1.5 & 16.6 & 49.8 & 91.1 \\
\hline 32 & 7.80 & 249.2 & 5880 & 2.0 & 3.7 & 0 & 0.5 & 21.5 & 52.7 & 97.6 \\
\hline
\end{tabular}

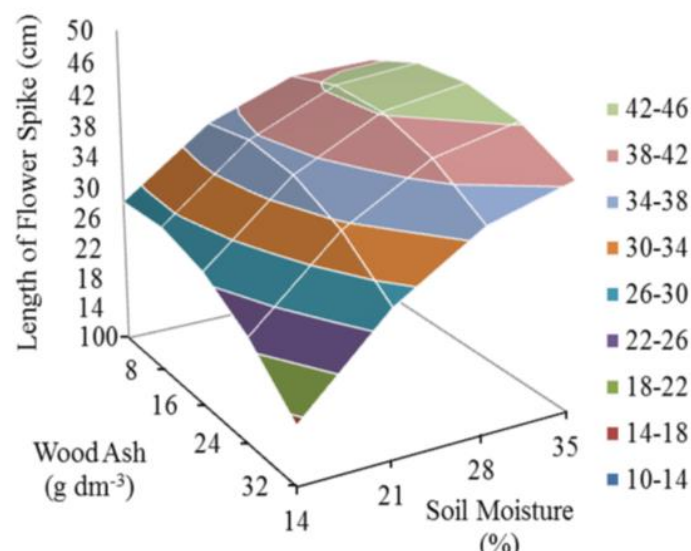

$\mathrm{LFS}=2.576157^{* * *} \theta-0.016043^{* *} \mathrm{WA}^{2}+0.012127^{*} \mathrm{WA} \theta-0.039883^{* *} \theta^{2}$ $\mathrm{R}^{2}=0.76$

Fig 3. Length of flower spikes (LFS) of gladiolus 'White Friendship' at harvest time according to combinations of wood ash (WA) doses and volumetric soil moistures $(\theta)$. ***, **, and *: significant at $0.1,1$, and $5 \%$, respectively.

Table 4. Brazilian marketing classification for gladiolus flowers (Barbosa, 2011).

\begin{tabular}{lcc}
\hline Classification & Flower Stem Length $(\mathrm{cm})$ & Flower Number Stem $^{-1}$ \\
\hline Extra & $>120$ & $>16$ \\
I & $100-120$ & $12-16$ \\
II & $80-100$ & $08-12$ \\
III & $60-80$ & $<8$ \\
\hline
\end{tabular}

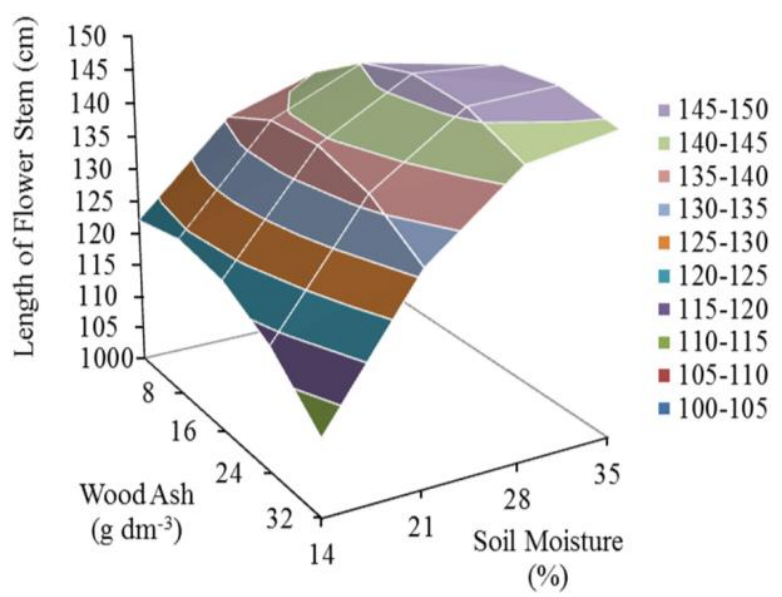

$\mathrm{LFS}=68.508257+5.081389 * * * \theta-0.023049 * \mathrm{WA}^{2}+0.028501 * * \mathrm{WA} \theta-0.089977 * * * \theta^{2}$ $\mathrm{R}^{2}=0.73$

Fig 4. Length of flower stems (LFS) of gladiolus 'White Friendship' at harvest time according to combinations of wood ash (WA) doses and volumetric soil moistures $(\theta) . * * * * *$, and $*$ : significant at $0.1,1$, and $5 \%$, respectively. 
elongation. Corroborating with these results, Pereira et al. (2009), when evaluating growth and flower production of gladiolus plants cultivated under different soil water pressures, verified that best quality of gladiolus flowers was obtained when irrigations were applied so that maximum soil water pressure was $15 \mathrm{kPa}$, which is close to field capacity. Furthermore, the authors also observed that at higher pressures, of $60 \mathrm{kPa}$, the mean length of flower stems was not enough to reach commercial standards, indicating, once more, susceptibility of this species to lower soil water contents.

\section{Flower numbers}

The variance analysis for flower numbers showed that there was no significant interaction among doses of wood ash and soil moisture at harvest time. However, there was an isolated significance for both factors, adjusted to the quadratic model (Fig. 5A and B). Maximum flower production, that is, 11.38 and 11.76 flowers stem $^{-1}$ was obtained when plants were cultivated under $11.64 \mathrm{~g} \mathrm{dm}^{-3}$ wood ash and $32.71 \%$ volumetric soil moisture, respectively. The response of the greater number of flowers in a gray dose of $11.64 \mathrm{~g} \mathrm{dm}^{-3}$ may be due to a greater concentration of magnesium present in its composition. Magnesium is the central compound of the chlorophyll molecule, therefore, it plays an important role in photosynthesis (Marschner, 1995; Hermans and Verbrudgen, 2005; White and Broadley, 2009). Thus, there was increased production of assimilates and translocation of these to the growth and development of gladiolus flowers (Çakmak et al., 1994), as the magnesium stimulates the formation of sugars, proteins, vegetable fats and vitamins that act in the thickening of the walls and permeability of cell membranes. According to Woltz (1955), nitrogen is responsible for the number of flower stems and flower buds per stem, while potassium directly affects flower stem length. Lehri et al. (2011) observed a positive response to the leaf length, number of flowers per stem with increasing nitrogen fertilizer to the dose of $175 \mathrm{~kg} \mathrm{ha}^{-1}$. Therefore, we highlight the influence applied by both phosphorus and potassium present in the wood ash on nitrogen absorption by the plant. Experimental results indicate that phosphorus deficiency limits nitrogen absorption by some crops and reduces nitrate absorption by Hordeum vulgare, Nicotiana tabacum, and Glycine max, among others. According to Rufty Júnior et al. (1993), the decrease in nitrogen absorption by phosphorus-deficient plants may be a consequence of several factors associated with the phosphorus stress condition. One possibility would be the reduction of the available energy (adenosine triphosphate) required for nitrate active absorption through the plasmalemma of root cells. About potassium, according to Stromberger et al. (1994), such nutrient takes part in many processes involving metabolism of nitrogen in plants; however, excess potassium restricts absorption of nitrogen. Halder et al. (2007) found that boron is essential throughout the cycle of gladiolus because, facilitates transport of carbohydrates through cell membrane, i.e starch and sugars as well as plays an important role as an activator for many enzymes which promote plant growth and flower production and increases the size of the corn. Thus, gladiolus showed a high boron requirement but within the tolerance limit of $2 \mathrm{~kg}$ ha $^{-1}$ (Rhoades et al., 1992). These results agree with Woltz (1954) and Halder et al. (2007), who found that higher boron induces growth in gladiolus foil and, consequently, a greater number of flowers. Basing on flower numbers, and according to the commercial classification of gladiolus flower stems (Table 3), the wood ash dose of $11.64 \mathrm{~g} \mathrm{dm}^{-3}$ and $32.71 \%$ volumetric soil moisture would be appropriate for production of flower stems classified as II; considering commercial economic values, such category would still generate a satisfactory income to the producer. Greater flower numbers obtained with increasing water levels was also observed by Bastug et al. (2006), that working with three irrigation treatments $(0,50,75$, and $100 \%$ evapotranspiration), reported a higher flowering percentage obtained when plants were cultivated under $86.2 \%$ water replacement level, followed by $75.2 \%$ and $58.1 \%$ levels. As Taiz and Zeiger (2006) reported, variations in water availability to a crop is subjective and may influence the physiological responses of the plant, since in water stress conditions (scarcity or excess), various physiological processes are changed, such as photosynthesis, stomatal opening, production of abscisic acid, leaf abscission and osmotic adjustment, thus dramatically reducing the productivity of ornamental plants. According to Pereira et al. (2009), ornamental plants, in general, are very susceptible to water level variations. Schwab (2011), in his experiment with pink Dianthus hybrid 'Melody', at different levels of irrigation and two crop cycles, observed similar behavior among anumber of flowers, and recommended the lowest percentage of water-holding capacity ( $40 \%$ of actual capacity storage). The plants when subjected to some form of environmental stress such as drought stress, increase abscisic acid accumulation. This is the hormone that inhibits various growth processes, but its most striking effect is associated with the natural fall of leaves and fruit. In addition to these effects it is responsible for inhibition of germination of many types of seeds, and causes some inhibition of flowering in plants.

\section{Number of days from plant flowering}

The wood ash dose of $8 \mathrm{~g} \mathrm{dm}^{-3}$ promoted a quadratic adjustment for a number of days from plant flowering, presenting the lowest value (around 50 days) (Fig. 6). Flowering is preceded by a period of elongation of the aerial part, and both phenomena are directly related. There was a time when induction of flowering was faster when plants had greater development, that is, when plants were cultivated without any addition of wood ash. The application of high doses of potassium fertilizer can cause nutritional imbalance in the plants, demonstrating the antagonistic effect of potassium in relation to the absorption of both calcium as well as magnesium, since all are cationic nutrients that compete strongly for the same absorption sites (Malavolta et al., 1997; Mascarenhas et al., 2000).

In comparison with control plants (no addition of wood ash), the dose of $8 \mathrm{~g} \mathrm{dm}^{-3}$ wood ash anticipated gladiolus flowering, while the greatest dose $\left(32 \mathrm{~g} \mathrm{dm}^{-3}\right)$ delayed it upto seven days (Fig. 6). Zubair et al. (2006) report that the application of $200 \mathrm{~kg} \mathrm{ha}^{-1} \mathrm{~K}_{2} \mathrm{SO}_{4}$ delayed flowering for upto 20 days, while $100 \mathrm{~kg} \mathrm{ha}^{-1}$ anticipated flowering to take place in eight days when compared with control plants $\left(0 \mathrm{~kg} \mathrm{ha}^{-1}\right)$. Bratti et al. (2012) in a study with plant gladioli, cultivate Peter pears grown in plastic containers of $5 \mathrm{~L}$ with limestone and potassium levels observed early flowering to 72.1 days after planting. We observed in the individual analysis of soil moisture, that there was a decrease in the number of days from plant emergence to flowering with moisture increase (Fig. 7). Soil moisture of $35 \%$ anticipated flowering in around six days when compared with $14 \%$ moisture. Therefore, it is possible to obtain earlier flowering with more frequent irrigation (Paiva et al., 1999). Such response of anticipation of flowering with soil moisture increase was also observed by Borges (2005) who worked with gladiolus 

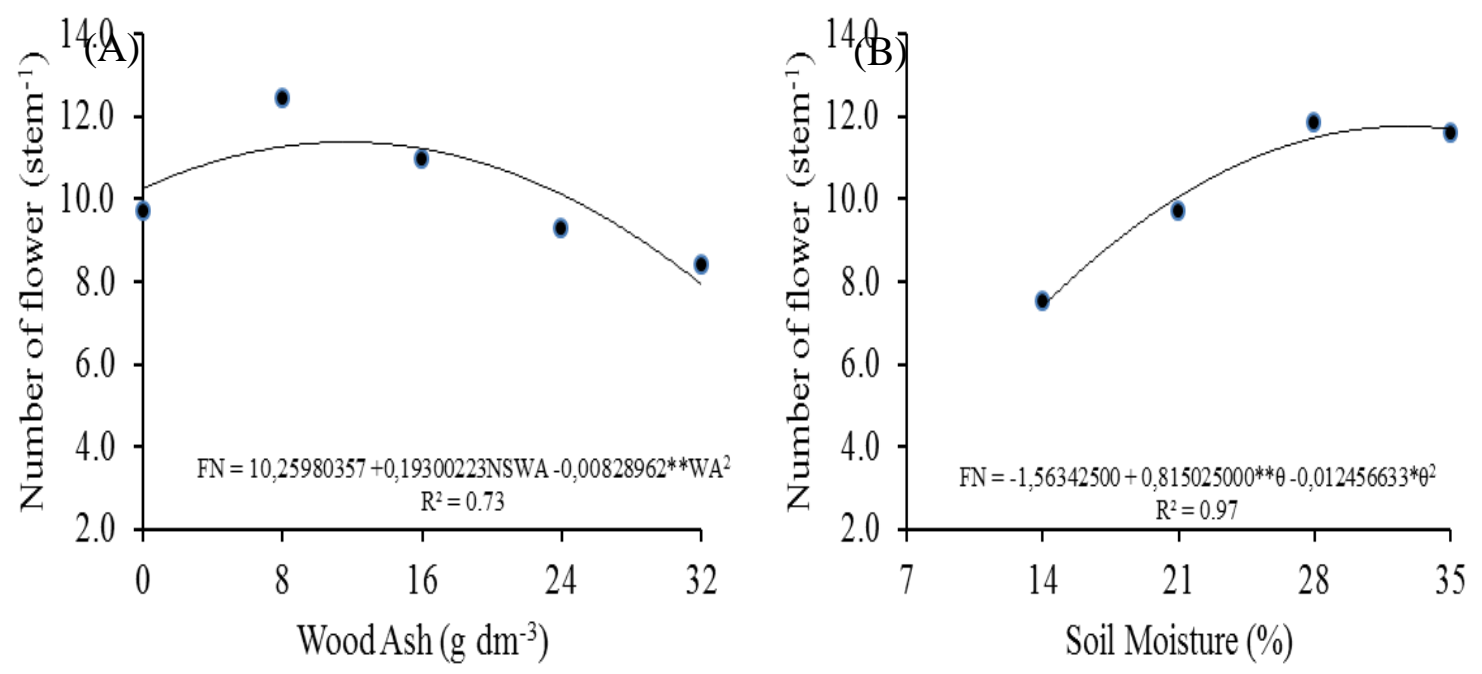

Fig 5. Flower numbers (FN) per stem of gladiolus 'White Friendship' according to wood ash (WA) doses; (A) and volumetric soil moistures $(\theta)$; (B) studied separately. $* *$ and $*$ : significant at 1 and $5 \%$, respectively; ${ }^{\mathrm{NS}}$ nonsignificant.

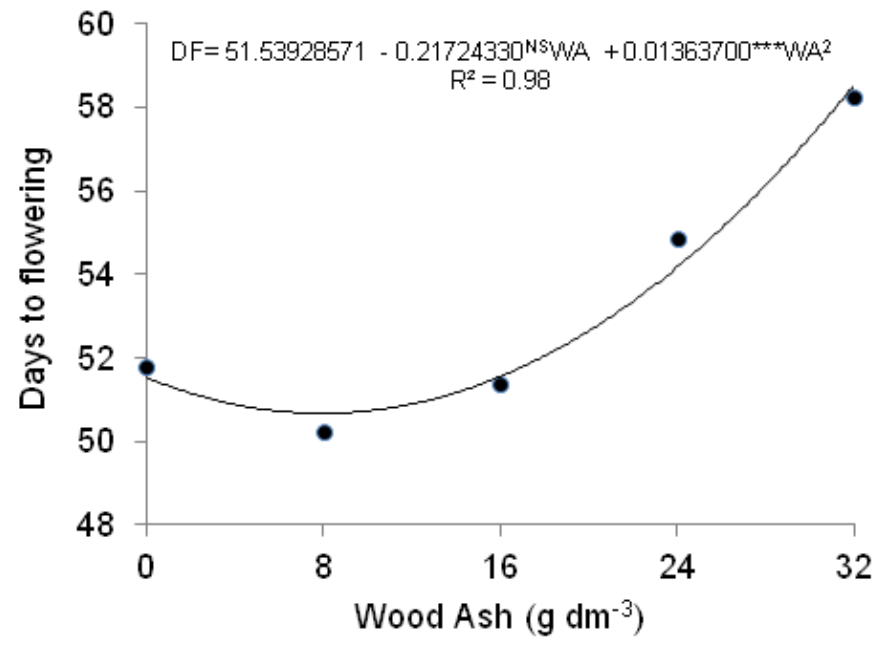

Fig 6. Number of days from plant flowering (DF) of gladiolus 'White Friendship' according to wood ash (WA) doses. ***Significant at $0.1 \%$; ${ }^{\mathrm{NS}}$ nonsignificant.

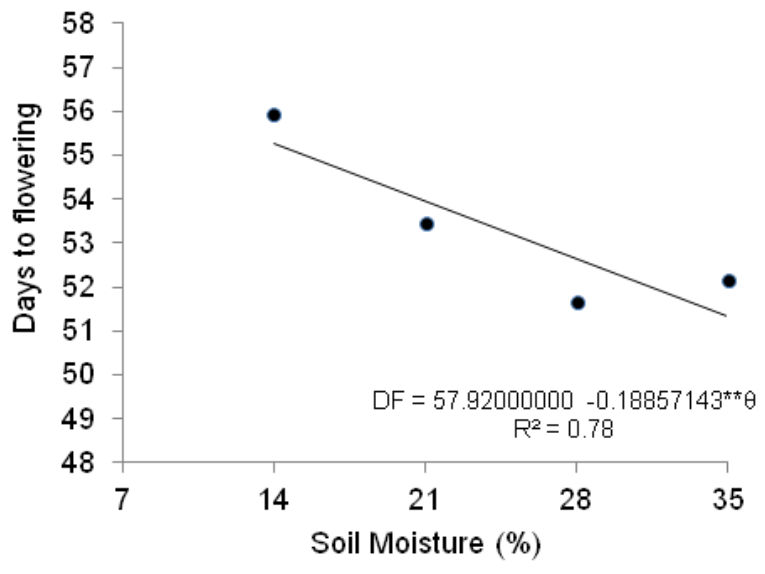

Fig 7. Number of days from plant flowering (DF) of gladiolus 'White Friendship' according to volumetric soil moistures $(\theta)$. **Significant at $1 \%$. 


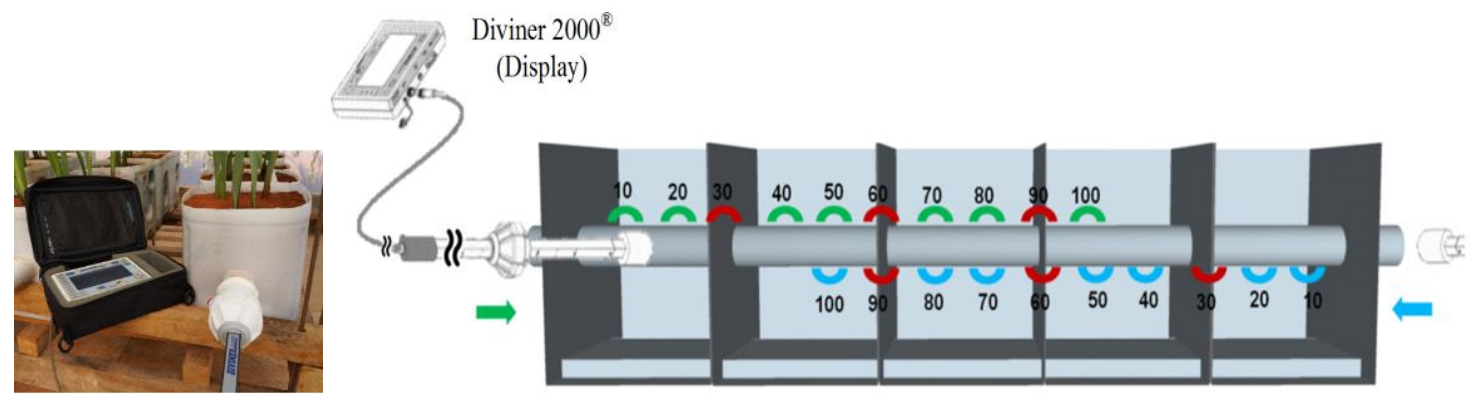

Fig 8. Diviner $2000^{\circledR}$ capacitance probe used in the experimental units. Side view scheme (section) of the experimental units with calibration of reading points for volumetric soil moisture measurement. Green and blue points were used; red points were excluded.

irrigation. According to Pereira et al. (2009), more frequent irrigation applied at the pressure of $15 \mathrm{kPa}$, does anticipate flowering. Shaukat et al. (2013) in gladiolus cultivar analysis in Pakistan under irrigated conditions observed in the cultivar Priscilla, a period of 80 days to flowering. It is worth highlighting that, for gladiolus, flowering achievement up to 60 days after plant emergence, verified for all treatments, was already expected, once this species is stimulated to flower earlier when cultivated in lower latitudes; on the contrary, when cultivated in higher altitudes, gladiolus flowering is delayed. This was evidenced by Boyle et al. (2009) in Boa Vista, Roraima State, Brazil (2 $\left.2^{\circ} 49^{\prime} 10^{\prime \prime} \mathrm{N}\right)$, and Zubair et al. (2006) in Peshawar, Pakistan $\left(34^{\circ} 00 ' 28^{\prime \prime} \mathrm{N}\right)$, who obtained flowering of gladiolus 'Peter pears' at 54 and 166 days after planting, respectively.

\section{Materials and Methods}

\section{Location and characteristics of the soil}

The experiment was conducted from April to June 2014, at the Federal University of Mato Grosso (UFMT) campus in Rondonópolis, Brazil, in a greenhouse belonging to the Institute of Agrarian and Technological Sciences (ICAT), geographically located at $16^{\circ} 27^{\prime}$ 'S latitude, 54\%34' W longitude, at an altitude of $284 \mathrm{~m}$. The soil used for the experiment was collected from a Cerrado vegetation area, from 0.00 to $0.20 \mathrm{~m}$ depth, and classified as a clay loam Rhodic Hapludox (Embrapa, 2013). Soil chemical and particle size characterization was performed (Table 1) according to Embrapa (1997).

\section{Experimental design and plant materials}

The experimental design was arranged in randomized blocks, in a $5 \times 5$ factorial scheme, totaling 25 treatments with four replications. Treatments were composed of five doses of wood ash $\left(0,8,16,24\right.$, and $\left.32 \mathrm{~g} \mathrm{dm}^{-3}\right)$, and five volumetric soil moistures $(7,14,21,28$, and $32 \%)$. The experimental units were organized into four blocks, with 25 units/treatments per block. The species used for the experiment was the Gladiolus x grandiflorus L., variety White Friendship, short cycle, equivalent to 60-65 days of cultivation.

\section{Soil fertilization and seeding}

The studied species was Gladiolus grandiflorus 'White Friendship'. Four corms were planted per experimental unit at a depth of $10 \mathrm{~cm}$.
Nitrogen fertilization $\left(90 \mathrm{mg} \mathrm{dm}{ }^{-3}\right.$ ) with urea was performed for all experimental plots. It was applied 14 days after plant emergence, and distributed in three applications at intervals of seven days. Wood ash was obtained from the burn of eucalyptus timber. Such material that has the ability to release some macronutrients and micronutrients in the soil, was submitted to the chemical characterization as a fertilizer (Table 2) according to the method established by Darolt et al. (1993). Furthermore, the effective calcium carbonate (ECC) in the wood ash was also calculated (Brasil, 2007), resulting in $21.02 \%$. In comparison with limestone, the wood ash ECC values were lower due to its minor neutralization power (Table 2). It is worth highlighting, however, that although the wood ash is composed of larger particles, these particles are desirable to obtain longer-lasting effects on soil correction and nutrient release to plants. Wood ash was incorporated into the soil, which was placed in 100 bags of $17 \mathrm{dm}^{3}$ capacity according to the described treatments. Soil moisture was kept at $60 \%$ soil water retention capacity. Wood ash incubation lasted a 30-day period that was expected for the wood ash-soil chemical reaction at the end of incubation, with the chemical characterization of each treatment (Table 3).

\section{Management of irrigation}

Irrigation management was performed via soil moisture measurement by the indirect method using a Diviner $2000^{\circledR}$ portable device (Fig. 8). To use a Diviner $2000^{\circledR}$ capacitance probe, calibration of reading points was done for each experimental unit. As this probe accomplishes readings at each $10 \mathrm{~cm}$ point, it was possible to validate points located in the center area of the pot (green and blue points), and exclude those closer to the boundaries of the pot (red points) (Fig. 8). For irrigation management, a mean of these readings was then calculated for each experimental unit. On the basis of the soil volume and current moisture in the pot, the necessary amount of water required to reach the desired volumetric soil moisture of each treatment was calculated (Eq. 1). Where: $\mathrm{V}=$ water volume, in $\mathrm{cm}^{3} ; \theta_{\text {treat }}=$ desired moisture for each treatment $(0.07,0.14,0.21,0.28$, and 0.32$)$, in $\mathrm{cm}^{3} \mathrm{~cm}^{-3} ; \theta_{\text {curr }}=$ soil moisture measured by the capacitance probe, in $\mathrm{cm}^{3} \mathrm{~cm}^{-3}$.

$\mathrm{V}=($ treat - - curr $) * 16500$ (Eq. 1)

Soil water retention capacity was calculated for each wood ash treatment according to the methodology described by Casoroli and Van Lier (2008). 


\section{Analyzed variables}

Soil $\mathrm{pH}$ was measured at 30 days after the wood ash-soil incubation, but before corm planting, and also at 150 days when the experimental period ended. Evaluation of flower production began when flower stems reached harvest time, that is when it was possible to observe flower color on the older bud (flower spike basis) (Barbosa, 2011). Length of flower spikes and flower stems (stem + flower spike) was measured (in $\mathrm{cm}$ ) using a measuring tape, from basal to apical flower bud, and from substrate surface to apical flower bud, respectively. When the basal flower was fully open, the number of flowers and days from plant emergence to flowering was evaluated per stem. At the end of the experimental period, flowers were classified according to flower stem length and flower number per stem, as suggested by Barbosa (2011), who based the related parameters on those established by Veiling Holambra Cooperative (Holambra, São Paulo State, Brazil), which is the Brazilian leader on the floriculture market (Table 4). The 7\% volumetric soil moisture treatment was not considered for statistical analysis of flower production, as these plants did not produce any flower stems.

\section{Statistical analyses}

Results were interpreted using the response surface analysis with SAS software (SAS, 2002); the polynomial regression (response surface analysis) was done using the RSREG procedure. When there were no significant interactions among factors, first- and second-degree regressions were applied at $5 \%$ probability using the GLM procedure.

\section{Conclusions}

Wood ash increases both soil water retention capacity and $\mathrm{pH}$ in Rhodic Hapludox. Combinations of appropriate doses of wood ash and soil moisture were found to promote greater length of flower spikes and flower stems, improving the commercial standards of gladiolus flowers. Wood ash promoted a higher number of flowers when plants were cultivated within the dose of $11.6 \mathrm{~g} \mathrm{dm}^{-3}$, and anticipated flowering when $8 \mathrm{~g} \mathrm{dm}^{-3}$ wood ash was applied. Increasing soil moisture anticipated gladiolus flowering and promoted a higher number of flowers when plants were cultivated under $33 \%$ volumetric soil moisture.

\section{References}

Adetunji MT (1997) Organic residue management and nutrient cycling. Agro-Ecosystems. 47:189-195.

Al-Humaid AI (2004) Adaptation of some gladiolus cultivars to al-qassim environmental conditions. Arab Gulf J Sci Res. 22:248-256.

Barbosa JG (2011) Palma de Santa Rita (gladíolo): produção comercial de flores e bulbos. Viçosa, Editora UFV. 113p

Bastos LM, Ferreira IM (2010) Composições fitofisionômicas do bioma cerrado: estudo sobre o subsistema de vereda. Espaço Verde. 12:97-108.

Bastug R, Karaguzel O, Aydinsakir K, Buyuktas D (2006) The effects of drip irrigation on flowering and flower quality of glasshouse gladiolus plant. Agr Water Manage. 81:132-144.

Bellote AFJ, Silva HD, Ferreira CA, Andrade GC (1998) Resíduos da indústria de celulose em plantios florestais. Bol Pesq Florest. 37:99-106.

Beutler AN, Centurion JF, Souza ZM, Andrioli I, Roque CG (2002) Retenção de água em dois tipos de Latossolos sob diferentes usos. Rev Bras Cienc Solo. 26:829-834.
Borges EG (2005) Rendimento, qualidade e precocidade de gladíolo irrigado no recôncavo baiano. 64f. Tese (Doutorado) Universidade Federal da Bahia, Cruz das Almas.

Boyle RL, Uchôa SCP, Santos CSV, Alves JMA, Albuquerque JAA, Martins SA (2009) Introdução e avaliação de gladíolos em ambiente de cerrado no Estado de Roraima. Rev Agro Amb Online. 3:36-41.

Brasil - Ministério da Agricultura (2007) Manual de métodos analíticos oficiais para fertilizantes minerais, orgânicos, organominerais e corretivos. (Secretaria Nacional de Defesa Agropecuária: Brasília. 141p.

Bratti EF, Rosa YBCJ, Silva EF, Rosa Júnior EJ, Zárate NAH, Bíscaro GA, Rosa DBCJ (2012) Cultivo de gladíolos em função das doses de calcário e potássio. Hortic Bras. 30:397402.

Cakmak I, Hengeler C, Marschener H (1994) Changes in phloem export of sucrose in leaves in response to phosphorus, potassium and magnesium deficiency in bean plants. J Exp Bot. 45:1251-1257.

Carvalho JA, Henriques EB, Paiva PDO, Pereira GM, Pereira JRD (2001) Crescimento e produção de hastes florais de gladíolo cultivado com déficit hídrico nas diferentes fases fenológicas. Rev Bras Hortic Ornam. 7:95-100.

Casaroli D, Van Lier QJV (2008) Critérios para determinação da capacidade de vaso. Rev Bras Cienc Solo. 32:59-66.

Conceição PC, Amado TJC, Mielniczuk J, Spagnollo E (2005) Qualidade do solo em sistemas de manejo avaliada pela dinâmica da matéria orgânica e atributos relacionados. Rev Bras Cienc Solo. 29:777-788.

Darolt MR, Bianco Neto V, Zambon FRA (1993) Cinza vegetal como fonte de nutrientes e corretivo de solo na cultura de alface. Rev Bras Hortic. 11:38-40.

Demeyer A, Nkana JCV, Verloo MG (2001) Characteristics of wood ash and influence on soil properties and nutrient uptake: an overview. Bioresource Technol. 77:287-295.

Embrapa - Empresa Brasileira de Pesquisa Agropecuária (1997) Manual de métodos de análises de solo. 212p. (Ministério da Agricultura e do Abastecimento: Rio de Janeiro).

Embrapa - Empresa Brasileira de Pesquisa Agropecuária (2013) Sistema brasileiro de classificação de solos. 353p. (Ministério da Agricultura e do Abastecimento: Brasília).

Ferreira EPB, Fageria NK, Didonet AD (2012) Chemical properties of an Oxisol under organic management as influenced by application of sugarcane bagasse ash. Rev Cienc Agron. 43:228-236.

Ferreira MM, Fernandes B, Curi N (1999) Influência da mineralogia da fração argila nas propriedades físicas de Latossolos da região sudeste do Brasil. Rev Bras Cienc Solo. 23:515-524

Guerrini LA, Villas Boas RL, Bull LT (1994) Influência do resíduo celulósico e cinza provenientes de fábrica de celulose e papel sobre algumas propriedades físicas, químicas e biológicas do solo em condições de vaso. Rev Cient. 22:43-51.

Halder NK, R Ahmed SM, Sharifuzzaman K, Anzu-Man-Ara B, Siddiky MA (2007) Efect of boron and zinc fertilization on corm and corm el production of gladiolus in grey terrace soils of Bangladesh. Int J Sust Prod. 2:85-89.

Halevy AH, (1962) Irrigation experiments with gladiolus. Adv Hortic Sci Appl. 2:484-492.

Haraldsen TK, Pedersen PA, Gronlund A (2011) Mixtures of bottom wood ash and meat and bone meal as NPK fertilizer. Recy Biomass Ashes. 3:33-44.

Hermans C, Verbruggen N (2005) Physiological characterization of $\mathrm{Mg}$ deficiency in arabidopsis thaliana. Journal Exp Bot. 56:2153-2161.

Igbokwe MC, Njoku BO, Odurukwe SO (1981) Liming effects on the response of maize on an ultisol in Enugu Nigeria. Nig J Soil Sci. 11:120-130.

Junqueira AH, Peetz MS (2014) O setor produtivo de flores e plantas ornamentais do Brasil, no período de 2008 a 2013: 
atualizações, balanços e perspectivas. Rev Bras Hortic Orname. 20:115-120.

Karaguzel O, Altan S, Doran I, Sogut Z (1999) The effects of $\mathrm{GA}_{3}$ and additional $\mathrm{KNO}_{3}$ fertilization on flowering and quality characteristics of gladiolus grandiflorus "eurovision". In: Anac D, Prevel PM. Imp Crop Quality Nutr Manage. 2:259-262.

Khanna PK, Raison RJ, Falkiner RA (1994) Chemical properties of ash derived from eucalyptus litter and its effects on forest soils. Forest Ecol Manag. 66:107-125.

Kiehl EJ (1979) Manual de edafologia: relações solo-planta. First Ed Agron Ceres, Piracicaba. 262p.

Lehri SM, Kurd AA, Rind MA, Bangulza NA (2011) The response of gladiolus tristis L. to $\mathrm{N}$ and $\mathrm{P}_{2} \mathrm{O}_{5}$ fertilizers. Sarhad J Agric. 27:185-188.

Lobermann-Eichler B, Schiemenz K, Makadi M, Vago I, Koppen D (2008) Nutrient cycling by using residues of bioenergy production - II Effects of biomass ashes on plant and soil parameters. Cereal Res Comm. 36:1259-1262.

Lopes AS (1998) Manual internacional de fertilidade do solo. Tradução e Adaptação. 2 ed. Piracicaba, Potafos. 177p.

Lu YT, Zhou DY, Shen SJ, Wang YJ, Chen AX, Yang SZ (1996) Study on gladiolus seed bulb production in South China. Acta Agric. 8:102-105

Maeda S, Silva HD, Cardoso C (2008) Resposta de Pinus taeda à aplicação de cinza de biomassa vegetal em Cambissolo Húmico em vaso. Pesq Florestal Bras. 28:43-52.

Malavolta E (1976) Manual de química agrícola: Nutrição de plantas e fertilizantes do solo. Ed Agron Ceres. 528p.

Marschner H (1995) Mineral nutrition of higher plants. Academic Press. 889p.

Mascarenhas HAA, Tanaka RT, Carmello QAC, Gallo PB, Ambrosano GMB (2000) Calcário e potássio para a cultura da soja. Scientia Agric. 57:445-449.

Mittra BN, Kramkar S, Swain DK, Gosh BC (2005) Fly ash: A potential source of soil amendment and a component of integrated plant nutrient supply system. Fuel. 84:1447-1451.

Moro L, Gonçalves JLM (1995) Efeitos da cinza de biomassa florestal sobre a produtividade de povoamentos puros de Eucalyptus grandis e avaliação financeira. Sci Forestalis. 48:18-27.

Mozaffari M, Russelle MP, Rosen CJ, Nater EA (2002) Nutrient supply and neutralizing value of alfalfa stem gasification ash. Soil Sci Soc Am J. 66:171-178.

Ndubuisi MC, Deborah N (2010) Response of maize (Zea mays L) to different rates of wood-ash application in acid ultisol in southeast Nigeria. J Am Sci. 6:53-57.

Nkana JCV, Demeyer A, Verloo MG (1998a) Availability of nutrients in wood ash amended tropical acid soils. Environ Technol. 19:1213-1221.

Nkana JCV, Demeyer A, Verloo MG (1998b) Chemical effects of wood ash on plant growth in tropical acid soils. Bioresource Technol. 63:251-260.

Norstrom SH, Bylund D, Vestin JLK, Lundstrom US (2012) Initial effects of wood ash application to soil and soil solution chemistry in a small, boreal catchment. Geoderma. 187:85-93.

Odedina SS, Odedina JN, Ayeni S, Arowojolu SA, Adedeye SO, Ojeniyi SO (2001) Effect of types of ash on soil fertility, nutrient availability and yield of tomatto and pepper. Nigerian J Soil Sci. 13:66-67.

Ojeniyi SO,Oso OP, Arotolu AA (2001) Response of vegetables to wood ash fertilizer. Proceedings of 35th Annual Conference of Agriculture Society of Nigeria. 39-43.

Omoti U, Obatolu CR, Fagbenro JÁ (1991) Complementary use of liming materials for tree and rainforest crops. First National Organic fertilizer seminar Kaduna Nigeria. 26-28.

Osaki F, Darolt MR (1991) Estudo da qualidade de cinzas vegetais para uso como adubos na região metropolitana de Curitiba. Rev Setor Cienc Agrar. 11:1-2.
Paiva PDO, Simões FC, Vieira FA, Fuini MG, Paiva R (1999) Cultura do Gladíolo. Lavras: UFLA - Departamento de Agricultura. 28p.

Park BB, Yanai R.D, Sahm JM, Lee DK, Abrahamson LP (2005) Wood ash effects on plant and soil in a willow bioenergy plantation. Biomass Bioenerg. 28:355-365.

Pereira JRD, Carvalho JA, Paiva PDO, Silva DJ, Souza AMG, Souza KJ (2009) Crescimento e produção de hastes florais de gladíolo cultivado sob diferentes tensões de água no solo. Cienc Agrotec. 33:965-970.

Prado RM, Corrêa MCM, Natale W (2002) Efeito da cinza da indústria de cerâmica no solo e na nutrição de mudas de goiabeira. Acta Sci. 24:1493-1500.

Reichardt K (1988) Capacidade de campo. Rev Bras Cienc Solo. 12:211-216.

Rhoades JD, Kandiah A, Mashali AM (1992) Use of saline waters for crop production. Irrig Drainage Paper. 48:133p.

Rigau A (1960) Los abonos: su preparaeion y emplego. Second ed. Editora Flores, Barcelona. 80p.

Rufty Júnior TW, Israel DW, Volk RJ, Qiu J, As T (1993) Phosphate regulation of nitrate assimilation in soybean. J Exper Bot. 44:879-891.

SAS Institute (2002) SAS: user's guide: statistics, 9th edn. Cary, 943p.

Schwab NT (2011) Disponibilidade hídrica no cultivo de cravina em vasos com substrato de cinza de casca de arroz. 80f Dissertação (Mestrado em Engenharia Agrícola) Universidade Federal de Santa Maria, Santa Maria.

Shaukat SA, Shah SZA, Shaukat SK, Shoukat SW (2013) Performance of gladiolus (gladiolus grandiflora L.) cultivars under the climatic conditions of bagh azad jammu and kashmir Pakistan. J C Eur Agric.14:158-167.

Silva FR (2008) Cinza de biomassa florestal: efeitos nos atributos de solos ácidos e na cultura do eucalipto. $67 \mathrm{f}$ Dissertação (mestrado) Centro de Ciências Agroveterinárias, Lages.

Silva FR, Albuquerque JA, Gatiboni LC, Costa A (2013) Uso da cinza da combustão de biomassa florestal como corretivo de acidez e fertilidade de um Cambissolo Húmico. Rev Cienc Agrovet.12:304-313.

Stromberger JA, Tsai CY, Huber DM (1994) Interactions of potassium with nitrogen and their influence on growth and yield potential in maize. J Plant Nutr.17:19-37.

Taiz L, Zeiger E (2006) Fisiologia Vegetal. Porto Alegre: Artmed, 3 ed. $719 \mathrm{p}$

Tombolato AFC (2004) Cultivo comercial de plantas ornamentais. Instituto Agronômico, Campinas. 211p.

White PJ, Broadley MR (2009) Biofortification of crops with seven mineral elements often lacking in human diets: iron, zinc, copper, calcium, magnesium, selenium and iodine. New Phytol. 182:49-84.

Woltz SS (1955) Effect of differential supplies of nitrogen, potassium and calcium on quality and yield of gladiolus flowers and corms. P Am Soc Hortic Sci. 6:427-435.

Woltz SS (1954) Studies on the nutritional requirements of gladiolus. Exp Stat J S. 296:330-335.

Zubair M, Ayub G, Wazir FK, Khan M, Mahmood Z (2006) Effect of potassium on preflowering growth of gladiolus cultivars. J Agric Biol Sci. 1:36-46. 